\title{
PERANG TARIF PENYEDIA LAYANAN OJEK DALAM JARINGAN DALAM PERSPEKTIF HUKUM PERSAINGAN USAHA DI INDONESIA
}

\author{
Rimarsha Agitta, Fakultas Hukum Universitas Udayana, E-mail: \\ rimarsha2108@gmail.com \\ Putu Ade Harriestha Martana, Fakultas Hukum Universitas Udayana E-mail: \\ ade_martana@unud.ac.id
}

doi : https://doi.org/10.24843/ks.2020.v09.i01.p08

\begin{abstract}
ABSTRAK
Penulisan jurnal ini bertujuan untuk mengetahui serta memahami perang tarif pada penyedia layanan ojek dalam jaringan dalam perspektif hukum persaingan usaha di Indonesia dan juga untuk mengetahui tugas Komisi Pengawas Perlindungan Usaha dalam mengawasi kasus persaingan usaha. Metode penelitian yang digunakan dalam jurnal ini adalah penelitian hukum normatif yang dimana mengkonsepsikan hukum dalam bentuk hukum yang sudah tertulis seperti undang-undang tertulis, dan bersifat deskriptif yaitu diartikan penelitian yang dilakukan dengan cara menggambarkan secara lengkap. Hasil penelitian menunjukkan bahwa perang tarif antara para penyedia layanan ojek daring yaitu PT. X dan PT. Y terdapat beberapa tanda dan pola praktik predatory pricing penetapan harga oleh perusahaan transportasi daring. Menurut UU No. 5 Tahun 1999 dikatakan bahwa PT. X dan PT. Y melawan hukum dengan tidak mengikuti aturan Pasal 5 ayat (1) UU No. 5 tahun 1999. Berdasarkan pasal tersebut sudah terbukti bahwasanya pihak PT. X dan PT. Y melanggar karena kedua perusahaan ojek daring tersebut melakukan perjanjian antara keduanya untuk menaikkan harga pada pelanggan ojek daring. Persaingan usaha memiliki lembaga pengawas yaitu Komisi Pengawas Persaingan Usaha (KPPU) yang dalam masalah persaingan usaha antara PT. X dan PT. Y ini berperan sebagai salah satu lembaga penegak hukum, dan tanggung jawabnya mengawasi perilaku persaingan usaha tidak sehat para pelaku usaha.
\end{abstract}

Kata kunci: Persaingan Usaha, Tarif, Jual Rugi, Ojek Daring

\begin{abstract}
In order to writing this journal is to know and understand the rates war between two corps who will be start to be some perspective from business competition in Indonesia and also to determine the role of the Business Protection Supervisory Commission. The research method used in this journal is normative legal research which conceptualizes law in the form of written law such as written law, and is descriptive in nature, which is defined as research that provides data about a situation or social symptoms that develop in the midst society in accordance with the facts and without any engineering. The results show that the tariff war between online motorcycle taxis, namely X Ltd. and $Y$ Ltd., has several signs and patterns of predatory pricing practices by online transportation companies, including discounts that reach unreasonable prices, long-term promotions that exceed standards. With that it can be said that X Ltd. and Y Ltd. violate Article 5 paragraph (1) of Law no. 5 of 1999. From this article, it has been proven that X Ltd. and Y Ltd. violated it because the two online motorcycle taxi companies entered into an agreement between the two of them to increase prices for online motorcycle taxi customers. In business competition, there is the Business Competition Supervisory Commission (KPPU), which in the business competition case between $X$
\end{abstract}


Ltd. and Y Ltd. plays a role as a law enforcement agency, and its responsibility is to supervise the unfair business competition behavior of business actors.

\section{Keywords: Business Competititon, Rates, Predatory Pricing, Online Transport.}

\section{Pendahuluan}

\subsection{Latar Belakang Masalah}

Hukum adalah sebuah penyatu untuk semua hal salah satunya untuk mengatur semua aspek kehidupan sosial, termasuk salah satunya adalah aspek ekonomi. Karena dapat dikatakan bahwa sumber daya ekonomi terbatas, dan di sisi lain tidak ada pembatasan permintaan sumber daya ekonomi, sehingga tidak terjadi bentrok rekan senegara saat bersaing memperebutkan sumber daya ekonomi tersebut. Tentunya, undang-undang memegang peranan penting dalam pembangunan ekonomi kesejahteraan masyarakat. Perkembangan ekonomi ini sangat bertepatan dengan munculnya globalisasi ekonomi. Pada saat yang sama, dunia usaha menghadapi tantangan yang semakin banyak, termasuk persaingan komersial atau perdagangan yang mengarah pada persaingan produk/komoditas dan tarif, karena perekonomian saat ini sudah antar negara dan terjadilah perdagangan global. ${ }^{1}$ Globalisasi juga menunjukkan perubahan yang mana terjadi pergerakkan yang cukup cepat atau bahkan sangat cepat, sehingga setiap perusahaan harus secara fleksibel memprediksi perubahan yang begitu cepat. ${ }^{2}$ Sekalipun telah disadari bahwa sukses atau tidaknya suatu perusahaan sangat ditentukan oleh berhasil tidaknya penerapan manajemen strategis dan manajemen pemasaran secara profesional dalam perusahaan, perusahaan dapat bertahan dan berkembang dalam persaingan bisnis yang semakin kompetitif saat ini. ${ }^{3}$

Persaingan terjadi disaat terdapat pihak-pihak yang ingin berlomba untuk menjadi yang terdepan demi menggapai keinginanan secara sempurna dengan melibatkan konsumen, bagian dari pasar, survey dan sumber daya yang dibutuhkan. ${ }^{4}$ Dengan adanya perlombaan untuk menjadi yang terdepan dalam kegiatan ekonomi maka muncullah sebuah persaingan yang dikhususkan oleh para pebisnis atau pengusaha yaitu, persaingan bisnis yang mana dapat diartikan sebagai rivalitas yang menyertai penjual, yang mana para pengusaha berusaha untuk mendapatkan keuntungan, pangsa pasar dan penjualan yang besar. Bagi para pebisnis, persaingan bisnis semacam ini sudah menjadi hal yang sangat biasa terjadi. Karena untuk setiap perusahaan harus mempertahankan konsumennya agar perusahaan tetap dapat berjalan dengan lancar. Namun bisa saja persaingan bisnis tersebut berubah menjadi persaingan yang tidak sehat. Persaingan usaha tidak sehat adalah persaingan yang

1 Makarao, Mohammad Taufik dan Suharsil. Hukum Larangan Praktik Monopoli dan Persaingan Usaha Tidak Sehat, (Bogor, Ghalia Indonesia, 2010), 3.

2 Salim, Al Idrus. "Solusi Strategis Organisasi Bisnis Menghadapi Persaingan di Era Global." IQTISHODUNA Jurnal Ekonomi dan Bisnis Islam 4, no. 3 (2008).

3 Pasigai, Muhammad Aris. "Pentingnya Konsep Dan Strategi Pemasaran Dalam Menghadapi Persaingan Bisnis." Jurnal Ekonomi Balance 5, no. 1 (2009): 51-56.

4 Kuncoro, Mudrajad. Strategi Bagaimana Meraih Keunggulan Kompetitif, (Jakarta, Erlangga, 2005), 86. 
terjadi diantara para pengusaha disaat terdapat kecurangan dalam menjalani usaha seperti tidak jujur dan melawan hukum atau menghambat persaingan usaha. ${ }^{5}$

Beberapa tahun terakhir ini menjadi ajang untuk pengusaha menciptakan inovasi baru salah satunya dengan adanya ojek yang dapat di pesan secara daring. Menurut Kamus Besar Bahasa Indonesia, ojek adalah sepeda atau sepeda motor yang ditambangkan dengan cara memboncengkan penumpang atau penyewanya. Mengingat zaman terus berkembang sehingga bagian transportasi pun tidak ingin ketinggalan zaman. Penyedia jasa ojek daring ini secara tiba-tiba banyak diminati oleh masyarakat. Semakin hari apalikasi ojek ini semakin banyak diminati masyarakat yang menyebabkan persaingan antara perusahaan menjadi semakin intens. ${ }^{6}$ Ojek sudah menjadi kebutuhan pokok warga perkotaan saat ingin untuk menerobos kemacetan di Ibukota. Perkembangan teknologi yang begitu pesat dapat membantu masyarakat saat masih membutuhkan transportasi yang nyaman, cepat dan efisien namun malas mengendarai transportasinya seperti motor. Maka dengan adanya bisnis daring yang menggarap ojek sebagai objeknya. Pada tahun 2011 ojek daring menjadi salah satu transportasi alternatif yang digunakan oleh banyak orang karena mengingat media transport ini mudah digunakan dan efisien. Pada awalnya ojek daring satu-satunya di Indonesia sebutlah PT. X . PT. X ini merupakan buatan asli Indonesia dengan pemiliknya adalah orang Indonesia, bernama Nadiem Makarim.

PT. X selalu menomor satukan kenyamanan konsumen dan peningkatan zaman yang memaksa harus selalu update. Pada tahun 2015 PT. X mulai berkembang pesat sehingga mengharuskan untuk menghadirkan aplikasi yang tersusun rapi agar pengguna tidak merasa kesulitan sedikitpun. Awal pendiriannya, PT. X melayani layanan jasa antar seperti layaknya kurir namun dengan menggunakan driver ojek untuk mengantarnya dengan syarat tempat pengiriman masih jangkauan dalam kota. Lalu terdapat jasa transportasi yaitu sebuah jasa ojek yang dapat mengantar kemanapun dengan harga yang masuk akal serta difasilitasi dengan pemberian masker dan tutup kepala secara gratis. Lalu ada jasa delivery makanan yaitu jasa dimana kita dapat membeli makan secara daring dengan syarat restoran harus bekerja sama dengan PT. X dengan biaya ongkos kirim yang terjangkau. Semua layanan tersebut saat itu baru beroperasi di Jabodetabek namun saat ini sudah hampir ada di seluruh kota di Indonesia. Dan yang terakhir adalah jasa belanja, pengguna dapat berbelanja secara daring apapun barangnya itu dengan sistem dibayarkan terlebih dahulu oleh para driver lalu saat sudah kita terima baru kita bayar sesuai nominal tetapi total pembelanjaannya dibatasi maksimal satu juta rupiah saja. Itulah jasa-jasa yang di tawarkan PT. X yang pertama beroperasi dengan aplikas sehingga membuat para pengguna merasa dimudahkan dalam hal apapun.

PT. X terbukti sukses dengan segala inovasi yang telah dibuatnya sehingga memiliki mitra sampai ratusan ribu driver ojek yang terdapat di hampir seluruh kota di Indonesia. Aplikasi PT. X ini berjalan dengan sukses sehingga aplikasinya diunduh lebih dari belasan juta kali di telfon genggam. Dengan munculnya PT. X ini dapat

5 Pribadi, Denny Slamet. "Larangan Praktik Monopoli dan Persaingan Usaha Tidak Sehat ditinjau dari Hukum Bisnis." Jurnal Aplikasi Manajemen 6, no. 3 (2020): 418-423.

6 Elvina, Magdalena. "Sikap Masyarakat Jakarta Pengguna Aplikasi Grab Terhadap Brand Baru Grab." Jurnal E-Komunikasi 4, no. 1 (2016). 
membuktikan bahwa kemunculan inovasi seperti ini dapat membuat banyak lapangan kerja baru untuk masyarakat.7

Setelah beberapa tahun PT. X menduduki peringkat pertama dalam hal ojek daring, lalu masuk perusahaan transportasi daring milik Malaysia ke Indonesia dengan mengenalkan salah satu produknya adalah juga ojek daring. Perusahaan tersebut adalah PT. Y. PT. Y merupakan pesaing yang berat dalam hal ojek daring ini. Meski mengalami pertumbuhan pesat dan pendanaan dalam jumlah besar, posisi PT. Y saat ini bukanlah nomor satu. Ketika perusahaan menempati urutan kedua, tekanannya sangat besar. Ini karena investor aktif mengejarnya, sehingga menjadikan perusahaan tersebut nomor satu. Demikian pula, PT. Y saat ini menduduki peringkat kedua, kedua setelah PT. X.

Sejak saat itu, terjadi persaingan perang tarif antara kedua ojek daring tersebut. Dan perang tarif ini dilakukan dengan cara memberikan promo untuk para pengguna, yang dikarenakan tarif dasar ojek daring pada dasarnya ditentukan secara sepihak oleh penyedia layanan. Apakah perang tarif tersebut merupakan persaingan usaha yang sehat/tidak sehat dan apakah KPPU berwenang untuk menanganinya.

State of the art diambil dari penelitian terdahulu yang sudah meneliti topik ini, yaitu berupa jurnal yang ditulis oleh I Dw Gd Riski Mada yang berjudul "Praktik Jual Rugi (Predatory Pricing) Pelaku Usaha Dalam Perspektif Persaingan Usaha" pada Jurnal Ilmu Hukum Kertha Semaya Volume 1 Nomor 6 Tahun 2013 yang meneliti mengenai dampak praktik jual rugi terhadap persaingan usaha dan akibat hukum terhadap pelaku usaha yang melakukan praktik jual rugi.

Berdasarkan penelitian terdahulu diatas maka penulis dapat membedakannya dengan jurnal ini, yaitu jurnal ini lebih membahas bagaimana perang tarif yang dilakukan para perusahaan ojek daring yang menjadi pesaing teratas saat ini dengan menggunakan undang-undang sebagai metode penelitiannya. Yang dimana ternyata para perusahaan ini melakukan pelanggaran dengan melakukan perang tarif ini. Berdasarkan latar belakang diatas maka penulis tertarik untuk membuat penelitian dengan judul "PERANG TARIF PENYEDIA LAYANAN OJEK DALAM JARINGAN DALAM PERSPEKTIF HUKUM PERSAINGAN USAHA DI INDONESIA".

\subsection{Rumusan Masalah}

Berdasarkan pada latar belakang yang telah diuraikan oleh penulis diatas, maka dapat dirumuskan suatu permasalahan yaitu:

1. Bagaimanakah pengaturan terkait dengan perang tarif pada Ojek Daring/Online Dalam Undang-Undang Nomor 5 Tahun 1999 tentang Larangan Praktek Monopoli Dan Persaingan Usaha Tidak Sehat?

2. Bagaimanakah peran Komisi Pengawas Persaingan Usaha dalam menangani persoalan perang tarif pada Ojek Daring/Online yang berpotensi menyebabkan terjadinya praktek monopoli dan persaingan usaha tidak sehat?

\subsection{Tujuan Penulisan}

Penulisan dari karya ilmiah ini mempunyai tujuan untuk mengetahui bagaimana Undang-Undang tentang Persaingan Usaha ini mengatur perang tarif pada Ojek Daring/Online. Serta untuk mengetahui bagaimana peran Komisi Pengawas

7 Flores, Onesimo, and Lisa Rayle. "How cities use regulation for innovation: the case of Uber, Lyft and Sidecar in San Francisco." Transportation research procedia 25 (2017): 3756-3768. 
Persaingan Usaha dalam menangani persoalan perang tarif pada Ojek Daring/ Online yang berpotensi menyebabkan terjadinya praktek monopoli dan persaingan usaha tidak sehat.

\section{Metode Penelitian}

Penelitian dalam karya ilmiah ini menggunakan penelitian hukum normatif yang dimana memiliki tujuan untuk meneliti norma hukum dan kaidah hukum. ${ }^{8}$ Penelitian ini bersifat deskriptif, yaitu penelitian yang dilakukan dengan cara menggambarkan secara lengkap tentang hal-hal yang berhubungan dengan permasalahan yang diteliti melalui melihat undang-undang yang mengatur dalam kasus yang digunakan dalam penulisan ini. ${ }^{9}$ Dalam meneliti, penulis menggunakan pendekatan perundangundangan yakni dilakukan dengan menelaah semua undang-undang dan regulasi terkait. Dan menggunakan pendekatan konseptual yang menggunakan konsep-konsep hukum untuk memecahkan masalah. Bahan hukum pada karya ilmiah ini dikumpulkan menggunakan teknik studi dokumen. Penelitian ini juga menggunakan Teknik Studi Pustaka dimana pengumpulan bahan hukum juga dilakukan melalui berbagai sumber seperti buku, karya ilmiah, internet, maupun litelatur lainnya yang mendukung penelitian ini.

\section{Hasil dan Pembahasan}

\subsection{Pengaturan Perang Tarif pada Ojek Daring/Online Dalam Undang-Undang Nomor 5 Tahun 1999 tentang Larangan Praktek Monopoli Dan Persaingan Usaha Tidak Sehat}

Bersaing diantara pelaku pebisnis merupakan hal yang biasa. Dalam pengertian umum, persaingan diartikan sebagai suatu kegiatan untuk mendapatkan keuntungan tanpa harus bersusah payah melakukan kegiatan usaha bisnis. Persaingan dalam konteks pemasaran seperti dikemukakan oleh Kotler dan Porter adalah situasi perusahaan bidang produk atau jasa tertentu berusaha mengedepankan keunggulannya masing-masing, berdasarkan peraturan atau bahkan tanpa peraturan tertentu untuk mendapatkan pelanggan. ${ }^{10}$ Maksudnya bisnis ialah sebuah kegiatan yang diciptakan untuk melakukan kegiatan ekonomi seperti produksi dan penjualan barang ataupun jasa yang mana nantinya akan mendapatkan keuntungan tetapi bisa juga berujung kerugian. ${ }^{11}$ Dalam kegiatan bisnis, kondisi lingkungan mencerminkan tingkat produksi dan konsumsi tertentu, dan pada akhirnya berdampak langsung pada penerimaan dan pengeluaran kondisi perusahaan. Dampak lingkungan bisnis terhadap kinerja perusahaan menggambarkan nilai bisnis itu sendiri. ${ }^{12}$

Pasal 1 UU No. 5 Tahun 1999 menjelaskan apa yang dimaksud dengan persaingaan tidak sehat, persaingan tidak sehat adalah persaingan yang dilakukan

8 Apriana, I. Putu Fajar, and Retno Murni. "Kegiatan Jual Rugi Dalam Persaingan Usaha: Suatu Kajian Yuridis." Kertha Semaya: Journal Ilmu Hukum 8, no. 2: 78-92.

9 Amiruddin, Zainal Asikin, Pengantar Metode Penelitian Hukum, (Jakarta, PT Raja Grafindo, 2004), 25.

10 Zain, Bilqis Nabila. "Analisis Swot Sebagai Perumusuan Strategi Competitive Advantage (Studi pada Dealer Yamaha Mekar Motor" Skripsi Fakultas Ekonomi Dan Bisnis Universitas Telkom, (2017), 1.

11 Juliyani, Erly. “Etika Bisnis dalam Perspektif Islam.” Jurnal Ummul Qura 7 no. 1 (2016): 63-74.

12 Priangani, Ade. "Analisis Lingkungan Global Dalam Persaingan Bisnis Internasional." Jurnal Kebangsaan 1, no. 2 (2012): 1-13. 
secara tidak jujur yang dilakukan oleh para pengusaha bidang apapun itu. Sesuai dengan ketentuan dalam pasal 11 UU No. 5 Tahun 1999 yang menetapkan bahwa adanya larangan untuk para pengusaha melakukan sebuah perjanjian dengan pesaingnya untuk melakukan penetapan harga karena itu sama dengan melakukan suatu praktik monopoli dan masuk ke indikasi bahwa perusahaan tersebut melakukan persaingan yang tidak sehat dalam berbisnis.

Salah satu bentuk persaingan yang tidak sehat yaitu adanya suatu predatory pricing dalam sebuah persaingan. Praktik predatory pricing adalah strategi penetapan harga di mana harga yang ditetapkan atas suatu produk atau layanan menjadi rendah dari harga pasaran industri dengan tujuan untuk menjangkau pelanggan baru, menyingkirkan pesaing, atau menciptakan hambatan bagi para pesaing. ${ }^{13}$

Dalam kasus perang tarif antara para ojek daring yaitu PT. X dan PT. Y terdapat beberapa tanda dan pola praktik predatory pricing penetapan harga oleh kedua perusahaan ini, antara lain menghadirkan potongan harga sampai-sampai pengguna hanya harus bayar 1 rupiah saja, dan hal itu berlangsung cukup lama. Sejak 1 Mei 2019, tarif ojek daring mulai diberlakukan, yang mendorong perusahaan angkutan daring giat menerapkan strategi promosi untuk menarik konsumen. Hal tersebut dapat menyebabkan persaingan yang tidak sehat serta dapat terjadi praktik monopoli. Komisi Pengawas Persaingan Usaha (KPPU) mencontohkan, pasca diberlakukannya tarif ojek online ini, terjadi praktik predatory pricing. Jika praktik ini dibiarkan, diperkirakan akan merugikan industri transportasi daring secara berkelanjutan. Dengan adanya praktik predatory pricing ini akan membuat perusahaan kehilangan keuntungan namun diperkirakan hanya sebentar tetapi perusahaan dapat optimis untuk segera mendapatkan keuntungan kembali dimasa yang akan datang dengan adanya penambahan pelanggan yang awalnya tertarik karena penerapan tarif yang murah. Dalam predatory pricing terdapat kriteria dan unsur yang harus dipenuhi, seperti. ${ }^{14}$

1. Harus adanya perjanjian diantara pengusaha yang telah memutuskan untuk bekerjasama menurunkan harga dibawah harga tetap.

2. Harga dibawah harga tetap dengan melihat situasi pasar, sehingga posisi pasar dengan harga pasar terjadi perbandingan.

Pada kasus ini, menurut Haryadin, seorang ekonom UI menjelaskan bahwa adanya hal promo-promo ini untuk membakar modal untuk penguasaan pasar. ${ }^{15}$ Dana tersebut digunakan untuk melaksanakan promosi skala besar dan diskon yang sangat tinggi untuk menarik perhatian orang. Penggunaan promo dan diskon akan menghasilkan harga yang tidak wajar. Harga yang tidak wajar ini terlihat dari perbedaan aplikasinya yaitu tarif yang didapat sesuai dengan jarak yang dibayarkan konsumen melalui potongan harga. Selain itu, harga yang ditengarai lebih rendah dari biaya produksi.

13 Mada, I Dw Gd Riski Mada, A.A Sri Indrawati. "Praktik Jual Rugi (Predatory Pricing) Pelaku Usaha Dalam Perspektif Persaingan Usaha" Kertha Semaya, Jurnal Ilmu Hukum 1, No. 6 (2013): 1-5.

14 Riva'i, Muchtar, and Darwin Erhandy. "Kebijakan Dan Hukum Persaingan Usaha Yang Sehat: Sinergitas Kawasan Asean di Era Globalisasi." Liquidity 2, no. 2 (2013): 195-204.

15 Dwi Hadya Jayani, 2019, Praktik Predatory Pricing di Ojek Online, Diakses dari https://katadata.co.id/safrezifitra/berita/5e9a518358779/praktik-predatory-pricing-diojek-online (Diakses pada tanggal 26 Juni 2019 pukul 09.18). 
Dengan ini PT. X dan PT. Y dapat dikatakan melanggar Pasal 5 ayat (1) UndangUndang Nomor 5 tahun 1999 tentang Larangan Praktek Monopoli Dan Persaingan Usaha Tidak Sehat, karena dalam pasal tersebut telah menyebutkan bahwa para pengusaha haram hukumnya untuk membuat perjanjian dengan pengusaha lainnya apalagi jika perjanjian tersbeut mengenai penetapan harga dan dilakukan pada pasar yang berkaitan. Dari pasal tersebut sudah terbukti bahwasanya pihak PT. X dan PT. Y melanggar karena kedua perusahaan ojek daring tersebut melakukan perjanjian antara keduanya untuk sama-sama menurunkan harga pada pelanggan ojek daring. ${ }^{16}$

Menurut Pasal 11 Undang-Undang Nomor 5 tahun 1999 tentang Larangan Praktek Monopoli Dan Persaingan Usaha Tidak Sehat, pengusaha dilarang membuat perjanjian dengan pengusaha lainnya jika bertujuan untuk merubah harga dengan cara-cara yang dapat menimbulkan perilaku monopoli dan/atau persaingan usaha tidak sehat., yang mana juga mereka langgar karena sangat memungkinkan bagi kedua perusahaan ojek daring tersebut untuk membuat standarisasinya sendiri tanpa sesuai dengan Undang-Undang yang seharusnya berlaku atau tanpa adanya peraturan yang mengikat. Dalam pendekatan rule of reason, apabila suatu kegiatan usaha dilarang dan tetap dilakukan oleh para pelaku usaha, maka dampak negatifnya akan terlihat, bukan dengan menyelesaikan apakah perilaku tersebut tidak adil atau melanggar hukum. Menurut Pasal 20 Undang-Undang Nomor 5 tahun 1999 tentang Larangan Praktek Monopoli Dan Persaingan Usaha Tidak Sehat menjelaskan bahwa "pelaku usaha dilarang melakukan pemasokan barang dan atau jasa dengan cara melakukan jual beli atau menetapkan harga yang sangat rendah dengan maksud untuk menyingkirkan atau mematikan usaha pesaingnya di pasar bersangkutan, sehingga dapat mengakibatkan terjadinya praktek monopoli dan atau persaingan usaha tidak sehat". Pada Undang-Undang diatas tentang Hukum Persaingan Usaha telah mengatur sebagaimana pelaku usaha dilarang untuk melakukan apapun praktik yang dapat penyebabkan persaingan usaha tidak sehat bahkan terdapat indikasi praktik monopoli. Apalagi jika dilakukan dengan memberi harga dibawah harga pasar. Pelaku usaha melakukannya dengan alasan ingin melindungi perusahaan demi peringkat yang dipunya. ${ }^{17}$

Apabila perang tarif ini tetap dilanjutkan, maka dapat menyebabkan salah satu perusahaan tersebut tutup karena perusahaan yang mampu bertahan adalah perusahaan yang memiliki dana kuat. Namun dibalik itu semua setiap perusahaan, yang bergerak dalam bidang apapun dalam menjalani aktivitasnya diperlukan strategi yang baik untuk dapat selalu bersaing dan akan mendapat keuntungan yang membuat perusahaan menduduki tempat terbaik. ${ }^{18}$

Sampai saat ini, pemimpin pasar operator layanan ojek daring di Indonesia adalah PT. X dan PT. Y, yang terus bersaing satu sama lain dengan kekuatan yang hampir sama dalam hal tarif, layanan, dan promosi. Persaingan yang ketat diantara kedua pemimpin pasar tersebut membuat daya tawar para pesaing menjadi sangat berharga. Setiap pesaing memiliki kepentingan strategisnya masing-masing, seperti

16 Vincent Fabian Thomas, 2018, Saat Gojek-Grab Perang Tarif, Kemenhub Hanya Bisa Diam, diakses dari https://tirto.id/saat-gojek-grab-perang-tarif-kemenhub-hanya-bisa-diam-da9t pada tanggal 6 Desember 2018.

17 Kurniasari, Mutiara. "Predatory Pricing pada Promo Grab ditinjau dari Undang-undang Nomor 5 Tahun 1999 tentang Praktek Monopoli dan Persaingan Usaha Tidak Sehat" Thesis Universitas Muhammadiyah Malang, (2020), 5.

18 Kuntjoroadi, Wibowo, dan Nurul Safitri. "Analisis strategi bersaing dalam persaingan usaha penerbangan komersial." Bisnis \& Birokrasi Journal 16, no. 1 (2011), 45-52. 
PT. X saat ini bertekad melebarkan sayap ke Asia dengan membuka cabang di India. PT. Y juga telah mengembangkan strategi untuk mengembangkan start-up lain yang merupakan anak perusahaan PT. Y sendiri.

\subsection{Peran Komisi Pengawas Persaingan Usaha (KPPU) dalam menangani persoalan perang tarif pada Ojek Daring/Online}

Komisi Pengawas Persaingan Usaha (KPPU) adalah sebuah badan negara yang dimana terbentuknya badan negara ini karena Keputusan Presiden Nomor 75 Tahun 1999 tentang Komisi Pengawas Persaingan Usaha. Yang mana bertugas sebagai suatu Lembaga untuk mengawasi para perushaan yang melakukan persaingan usaha. Menurut Pasal 35 Undang-Undang No. 5 Tahun 1999, tugas KPPU yang berhubungan dalam kasus persaingan usaha ojek daring ini meliputi:

1. melakukan penilaian terhadap perjanjian yang dapat mengakibatkan terjadinya praktek monopoli dan atau persaingan usaha tidak sehat sebagaimana diatur dalam Pasal 4 sampai dengan Pasal 16;

2. melakukan penilaian terhadap kegiatan usaha dan atau tindakan pelaku usaha yang dapat mengakibatkan terjadinya praktek monopoli dan atau persaingan usaha tidak sehat sebagaimana diatur dalam Pasal 17 sampai dengan Pasal 24;

Kaitan dengan penjelasan yang terdapat pada pembahasan pertama adalah KPPU dapat menindaklanjuti kasus diatas karena adanya perjanjian yang dilakukan oleh PT. X dan PT. Y yang mengakibatkan praktik monopoli dan/atau persaingan tidak sehat, kedua perusahaan tersebut melanggar Pasal 4 sampai dengan Pasal 16 UU No. 5 Tahun 1999. Dan juga karena tidak ada perjanjian adanya kegiatan dan/atau tindakan pelaku usaha yang mengakibatkan praktik monopoli dan/atau persaingan tidak sehat, dan karena itu kedua perusahaan tersebut melanggar Pasal 17 sampai dengan Pasal 24 UU No. 5 Tahun 1999.

Dalam hal ini, masalah predatory pricing adalah masalah yang tertera dalam Hukum Persaingan Usaha dimana jika melanggar akan mendapat sanksi sesuai dengan ketentuan Pasal 47 Undang-Undang Persaingan Usaha. Menurut sanksi administratif pada Pasal 47 ayat (2) huruf c dan huruf d serta Pasal 48 (2) dan 49 huruf $a$, huruf $b$, dan huruf c memberikan sanksi pidana pokok dan tambahan.

Jika salah satu pihak merasa keberatan atau terbebani atas keputusan yang telah dijatuhkan oleh KPPU maka sebaiknya melakukan nota keberatan ke Pengadilan Negeri dan apabila masih tidak puas bisa mengajukan Kasasi ke Mahkamah Agung. KPPU hanya dapat menangani masalah seperti ini dengan syarat bahwa pihak-pihaknya adalah pelaku usaha yang melakukan bisnis nya di wilayah Republik Indonesia. Hal ini disebabkan semakin banyaknya kegiatan usaha di berbagai bidang dan penyesuaian strategi untuk memenangkan persaingan antar pesaing. ${ }^{19}$

\section{Kesimpulan}

Berdasarkan pembahasan di atas, dapat disimpulkan bahwa berkaca pada UU No. 5 Tahun 1999 bahwa dijelaskan mengenai aturan dalam melakukan persaingan

19 Marhaeni, Luh Mita, and Anak Agung Gde Oka Parwata. "Peran Komisi Pengawas Persaingan Usaha (Kppu) Dalam Mencegah Terjadinya Praktek Monopoli Melalui Kartel" Kertha Semaya, Journal Ilmu Hukum 2, No. 3 (2014): 1-13. 
bisnis. Dalam Pasal 1 Angka 6 UU No. 5 Tahun 1999 menjelaskan apa yang dimaksud dengan persaingan tidak sehat. Dan juga sesuai dengan Pasal 11 UU No. 5 Tahun 1999 yang menetapkan bahwa adanya larangan untuk para pengusaha melakukan sebuah perjanjian dengan pesaingnya untuk melakukan penetapan harga sehingga dapat mengakibatkan perusahaan tersebut terindikasi melakukan persaingan yang tidak sehat dalam berbisnis. Sesuai dengan kasus PT. X dan PT. Y, kedua perusahaan tersebut melanggar Pasal 5 ayat (1) UU No. 5 Tahun 1999, karena PT. X terbukti melakukan sebuah perjanjian kepada PT. Y dengan isi perjanjian menurunkan harga dan menetapkan harga dibawah harga pasar. PT. X dan PT. Y terdapat beberapa tanda dan pola praktik predatory pricing penetapan harga oleh perusahaan transportasi daring, yaitu dengan melakukan pemotongan harga yang cukup besar. Dalam permasalahan persaingan usaha terdapat lembaga pengawasannya, yaitu KPPU. KPPU merupakan lembaga yang dibuat untuk mengawasi perusahaan dalam melakukan persaingan usaha. KPPU memiliki tugas yang telah diatur dalam pasal UU No. 5 Tahun 1999 terdapat 2 tugas yang berkaitan kasus ini yang dapat diawasi oleh KPPU. Tugas KPPU hanyalah sebagai Lembaga pengawas, KPPU tidak dapat melakukan penjatuhan sanksi atas pihak yang bersalah. Dengan adanya KPPU sekiranya dapat meminimalisir adanya pelanggaran-pelanggaran dilakukan suatu perusahaan demi menjatuhkan lawan bisnisnya.

\section{DAFTAR PUSTAKA}

\section{Buku:}

Amiruddin, Zainal Asikin, Pengantar Metode Penelitian Hukum, (Jakarta, PT Raja Grafindo, 2004), 25.

Kuncoro, Mudrajad. Strategi Bagaimana Meraih Keunggulan Kompetitif, (Jakarta, Erlangga, 2005), 86.

Makarao, Mohammad Taufik dan Suharsil. Hukum Larangan Praktik Monopoli dan Persaingan Usaha Tidak Sehat, (Bogor, Ghalia Indonesia, 2010), 3.

\section{Jurnal:}

Apriana, I. Putu Fajar, and Retno Murni. "Kegiatan Jual Rugi Dalam Persaingan Usaha: Suatu Kajian Yuridis." Kertha Semaya: Journal Ilmu Hukum 8, no. 2: 78-92.

Elvina, Magdalena. "Sikap Masyarakat Jakarta Pengguna Aplikasi Grab Terhadap Brand Baru Grab." Jurnal E-Komunikasi 4, no. 1 (2016).

Flores, Onesimo, and Lisa Rayle. "How cities use regulation for innovation: the case of Uber, Lyft and Sidecar in San Francisco." Transportation research procedia 25 (2017): 3756-3768.

Juliyani, Erly. “Etika Bisnis dalam Perspektif Islam." Jurnal Ummul Qura 7 no. 1 (2016): 63-74.

Kuntjoroadi, Wibowo, dan Nurul Safitri. "Analisis Strategi Bersaing Dalam Persaingan Usaha Penerbangan Komersial." Bisnis E Birokrasi Journal 16, no. 1 (2011), 4552.

Mada, I Dw Gd Riski Mada, A.A Sri Indrawati. “Praktik Jual Rugi (Predatory Pricing) Pelaku Usaha Dalam Perspektif Persaingan Usaha" Kertha Semaya, Jurnal Ilmu Hukum 1, No. 6 (2013): 1-5. 
Marhaeni, Luh Mita, and Anak Agung Gde Oka Parwata. "Peran Komisi Pengawas Persaingan Usaha (Kppu) Dalam Mencegah Terjadinya Praktek Monopoli Melalui Kartel" Kertha Semaya, Journal Ilmu Hukum 2, No. 3 (2014): 1-13.

Pasigai, Muhammad Aris. "Pentingnya Konsep Dan Strategi Pemasaran Dalam Menghadapi Persaingan Bisnis." Jurnal Ekonomi Balance 5, no. 1 (2009): 51-56.

Priangani, Ade. "Analisis Lingkungan Global Dalam Persaingan Bisnis Internasional." Jurnal Kebangsaan 1, no. 2 (2012): 1-13.

Pribadi, Denny Slamet. "Larangan Praktik Monopoli dan Persaingan Usaha Tidak Sehat ditinjau dari Hukum Bisnis." Jurnal Aplikasi Manajemen 6, no. 3 (2020): 418-423.

Riva'i, Muchtar, and Darwin Erhandy. "Kebijakan Dan Hukum Persaingan Usaha Yang Sehat: Sinergitas Kawasan Asean di Era Globalisasi." Liquidity 2, no. 2 (2013): 195-204.

Salim, Al Idrus. "Solusi Strategis Organisasi Bisnis Menghadapi Persaingan di Era Global." IQTISHODUNA Jurnal Ekonomi dan Bisnis Islam 4, no. 3 (2008).

\section{Tesis/Skripsi:}

Kurniasari, Mutiara. "Predatory Pricing pada Promo Grab ditinjau dari Undangundang Nomor 5 Tahun 1999 tentang Praktek Monopoli dan Persaingan Usaha Tidak Sehat" Thesis Universitas Muhammadiyah Malang, (2020), 5.

Zain, Bilqis Nabila. "Analisis Swot Sebagai Perumusuan Strategi Competitive Advantage (Studi pada Dealer Yamaha Mekar Motor" Skripsi Fakultas Ekonomi Dan Bisnis Universitas Telkom, (2017), 1.

\section{Internet:}

Dwi Hadya Jayani, 2019, Praktik Predatory Pricing di Ojek Online, Diakses dari https://katadata.co.id/safrezifitra/berita/5e9a518358779/praktik-predatorypricing-di-ojek-online pada tanggal 26 Juni 2019 pukul 09.18.

Vincent Fabian Thomas, 2018, Saat Gojek-Grab Perang Tarif, Kemenhub Hanya Bisa Diam, diakses dari https://tirto.id/saat-gojek-grab-perang-tarif-kemenhubhanya-bisa-diam-da9t pada tanggal 6 Desember 2018.

\section{Peraturan Perundang-Undangan:}

Undang-Undang No. 5 Tahun 1999 Tentang Larangan Praktek Monopoli dan Persaingan Usaha Tidak Sehat (Lembaran Negara Republik Indonesia Tahun 1999 Nomor 33, Tambahan Lembaran Negara Republik Indonesia Nomor 3817)

Keputusan Presiden Nomor 75 Tahun 1999 tentang Komisi Pengawas Persaingan Usaha 